\title{
精密測定シリーズ 9
}

\section{最近の真円度測定 \\ 味岡 成康* 川端 文雄*}

\section{1. まえがき}

機械工業において用いられる機械部品の形状は，その 添とえどが直線 (平面) と円 (円筒面) とを基璴こして 構成されている。これらのうち，特に円形部分を持つ部 品注, 齐種工作機械の回転主軸, およびその軸受, 父密 を要する部分の部品（スリーブとスプール，プランジャ 一とバレル)などのように, 高精度を必要とする機械装 置の主要部分に多く用いられている。

最近の機械工業の進展に伴って，これらの機械部品の 円形部分は，それぞれの機能を果すためにますますせま い許容限界内で丸いこと，すなわち真円度の良いここが 強く要望され，高精度を必要とするこれらの機械部品の 数も著しく増大してきた。最近の調査によれ証，このた め沉，真円度を高精度で，しかも能率的汇測定して，精 度管理を行なうことが必要になってきた。

そこで，各種機械部品が，現実にどの程度の真円度を 必要としているかといらことが, 真円度の測定精度に関 連して重要な問題になる。この点について, 鋤柄〉は, 約1500個の部品の円形部分の形状と，半径法真问度と 測定して，円形部分の多くが棈円と三角形とに類似して 形状であること，および真円度の值のほとえどが，0，

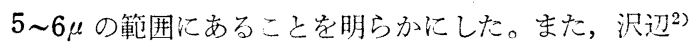
は, 精機学会の「形状精度㧍よび位置精度の許容值工業 標準原案委員会」および「形状および位置精度の許容値 に関する分科会」が行なった直径法真円度の調査資料を 整理して，直径法真円度の公差が $1 \sim 40 \mu$ の範囲に多く 存在することを明らかにした。また，この調查により真 円度が問題になる機械部品の直径は，大多数が 10 300 mmであることも明らかになった。

以上に述べたと打り，最近，重要性を増してきた真円 度の測定では, 特に以下の点が必要である。

(1) 多くの部品を能率的に測定できること。

（2） $0.5 \mu$ の測定が正確にできるために，測定精度は $0.1 \mu$ 程度であること。

(3) 直径 200 300mmの 円形部分まで測定できるこ と。

一方, 真円度を求める測定法は, 各国規格 ( J I S B

* 正会員 小坂研究所
-0607, DIN 7182，ASA Y-1 4，5，BS 3730）に見ら れるとおり大別して 3 種類，寸なわち， 3 点法，直径法， および半径法に分けられる。

ここで，前二者は理論的汇厳密さがないが，特別な装 置を用いないで容易に求めら机るので，便宣的な方法と して工業的に広く用いられている。

これらに対し，半径法は円形部分の輪郭から定まった 方式にしたがって輪郭の中心を求め，この中心を基準と して，一般には輪郭をでの距離——これを円形部分の半 径という一の偏差の最大值をもって真円度を求める方 法であって，理論的に厳密な方法である。

最近高精度の円形部分を数多く測定する必要が生じて くるにつれて，半径法真円度を能率的に測定することが 強く要求されて来た。このため, この方法について最近 測定が盛えになるとともに，簡単な操作で求められる測 定器が種々開発されてきた ${ }^{3), 4) 。 ~}$

そこで, 以下には, 半径法真円度の測定について, 詳 述することにする。

\section{2. 半径法における中心の求め方とその真円度}

半径法真円度は, 円形部分の輸郭の中心を求める方式 によって種々の異なった值が得られる。いま，円形部分 の断面図形が 図 1 (a) に示すとおりであるとすると, この図形から中心を求好方式として, 現在用いられて いるのは, 図1 (b)〜 (e) に示す方式である。

図 1 (b) に示す方式は, 図形化外接する円を画きさ らにこの円の中心を中心とする円接円を画き，両円の半 径差 $\delta_{b}$ をもって真円度を求める方式であって, 外接円 中心方式という。

図 1 (c) は，輪郭図形に内接する円の中心を基準と して真円度 $\delta \mathrm{c}$ を求める方式であって内接円中心方式と いう。

図1 (d) は，輪郭仙内接および外接する同心円のう 台, 両者の半径差 $\delta d$ が最小となる同心円の中心を基準 とする方式であって，最小領域中心方式といい，IＳＯ の形状精度の求め方に基ゔく方式である。

図 1 (e) は, 図形から最小自乗法で平均円を求め, この円の中心を基準として, 半径の最大值と最小值との 差 $\delta e$ で真円度を求める方式であって, 平均円中心方式 といわれる。JIS B-0607 记記載されている方式も，こ 


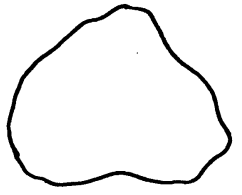

(a)

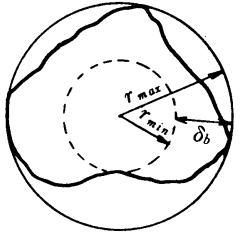

b) 外接円巾心法 (Ring gauge centre) $\delta_{b}=r_{\max }-r_{\text {min }}=22 \mu$

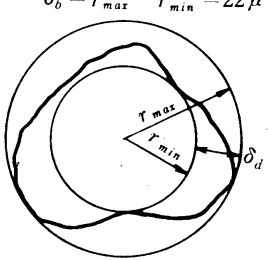

d）最小領域中心法 (Minimum zone centre) $\delta_{d}=18 \mu$

図 1 半径法に打ける中心の求め方

れと同じ概念に基づいていて，この方式が理論的にもっ とも厳密である。

上記 4 方式のうち，前三者は，いずれも輪郭の記録図 形から求めることができるが，平均円中心方式は，簡単 でない。この方式の中心を図形から求める場合の一方法 を次に述べる。いま，図 2 に示すとおりの輪郭図形が得 られたとすると，この図形の中央と考えられる所に原点 0 をとり，図形を等しい角度で分割した図形上の点 $P_{1} \sim$ $p_{n}$ の $X, Y$ 座標を求める。そして,

$$
a=\frac{2 \sum X}{n} \quad b=\frac{2 \sum Y}{n}
$$

を計算すれば，この $a, b$ が平均円の中心の座標である。 平均円の半径は, $O P_{1} \sim O P_{\mathrm{n}}$ の長さを $r_{1} \sim r_{\mathrm{n}}$ とした とき

$$
R=\frac{\dot{\sum} r}{n}
$$

で求められる。最近の電気技術を応用すれば，円形部分 の輪郭から得られる信号を用いて, 電気回路で上記の計 算を自動的に行なうことができるから，平均円を求める ことは，それ梳ど困難ではない8)。したがって，この平均 円の外側にある輪郭部分の平均円からの最大距離と, 平 均円の内側にある輪郭部分のうち，平均円からもっとも

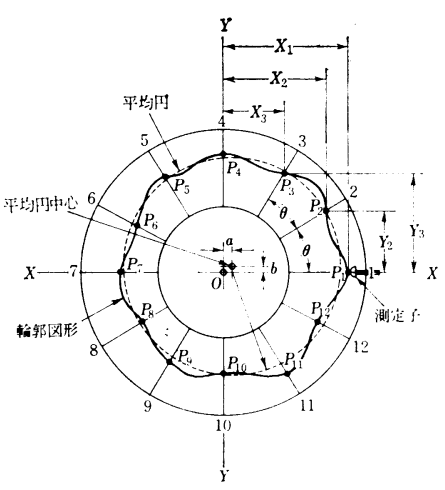

図 2 平均円中心の求め方

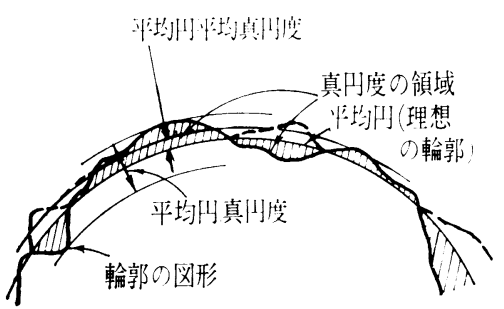

図 3 平均円真円度と平均円平均真円度

離机た点までの距離とを電気的に求め，さらに両者の和 $\left(\delta_{e}\right)$ を電気的に求めれば，平均円中心方式の真円度を 直接指示計に指示させることができる7)。

さらに，平均円とその両側にある輪郭とでかこまれた 面積 (図 3 の斜線部分) の総和を平均円の円周の長さた 除した值を電気的に求めることもできる7。。の值は, 表面あらさにおける中心線平均あらさに相当するものた あって，平均円平均真円度ということができよう。この 平均真円度は, 輪郭の形状を平均化した值であるから, 極端にとびでた山や極端にひっっこえだ谷などによって真 円度の值が左右されないで，形状の狂いを量的に表わ亦 ことができる点ですぐれている。したがって，この值の 採用と, 実際の精度管理の応用とは今後の研究課題であ ろう。

\section{3. 円形部分の輪郭の求め方}

外接円中心方式，内接円中心方式および最小領域中心 方式は，いずれも円形部分の輪郭図形を求めることが必 要である。また，平均円中心方式でも輪郭に応じた電気 信号を求める必要がある。そこで，つぎに円形部分の輪 郭の求め方について述べる。

輪郭の測定は，図 4 (a) に示すとおり，被測定物の まわりに測定子を回転させるか，図 4 (b) に示すとお 
り，測定子を被側定物に接触させた状態で被測定物を回 転させると, 形状に応じて測定子が動くから，この動き を差動変圧器などを用いて電気信号に変換し，乙れを増 蝠して曲座標記録計に入れ，拡大記録図形を求めて行な う，この場合には，回転軸心外の一点が軸の回転によっ て画く運動の軌跡を測定の基準とし，これと円形部分の 形状との相異だけを拡大して図 1 (a) に示すような図 形を画かせるものであるから，もし，回転軸心が振れる と，これが直接測定誤差となって現われる。そこで，回 転運動の誤差は, 検出する必要のある值よりも一段と小 さくなければならない。

なお, 図 4 (a) に示す検出器回転方式では, 被測定 特の重さが回転装置に加わらないので, 回転精度は被測 定物の重さ, 大きさに無関係で安定している利点があ る。この方式の代表的な測定器としては, 図5に示す Talyrond がある。また被測定物を回転する方式では, 真円度のほかに円筒面の母線の真直度等各種の測定を合 引せて行なう構造多持たせられる利点がある。この方式 つ代表的な測定器としては, 図6に示す Formtester が ある。

\section{4. 検出山数の大きさ，または検出周波数}

円形部分の輪郭を求める際，考えなければならないの は，輪郭上のぞの程度の山数なで検出するかということ である。真円度測定であるから輪郭上の表面あらさや小 さならねりを検出する必要はない。B S 3730 では, 円形部分の一円嗝上にある山のう方 500 山までを検出す れ、゙よい上している。さらに研削びびりがあり，これも 検出するとき,一円周上 500 山または 150 山まででよく， 円形部分の多角形の状態を測定するときには，15 山， 50 山までの検出を行なえばよいと考えている。

このように，検出山数を規定して輪郭の測定を行なう にあたっては, 測定子の先端半径の大きさ, 測定子の動 特性, 変換器の周波数特性, 電気回路上の周波数特性, および記録計のペンの追往特性を検討して沶かなければ ならない。

\section{1 測定子の形状と動特性}

いま, 円形部分の直径を $\mathrm{Dmm}$, 検计最大山数を $n$ と すると, この山の平均間隔 $P_{1}$ は

$$
P_{1}=\frac{\pi d}{n}
$$

となる。測定子の先端半径 $r \mathrm{~mm}$ は， $P_{1}$ より小さくな けれ泣，測定誤差が大きくならから，r<P である。こ の関係は，測定できる直径 $D$ が最小のときでも成立し なけ机ばならない。したがって, Dmini $=5 \mathrm{~mm}, n=500$

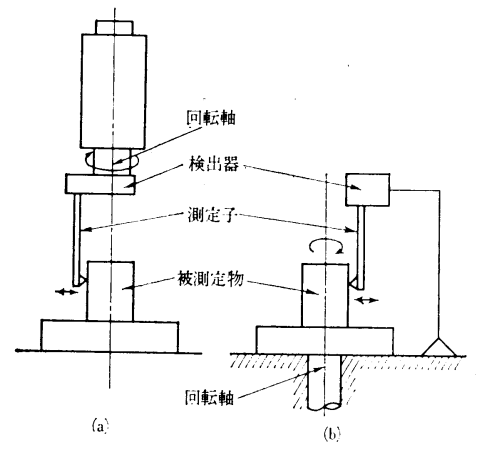

図 4 輪郭の求め方

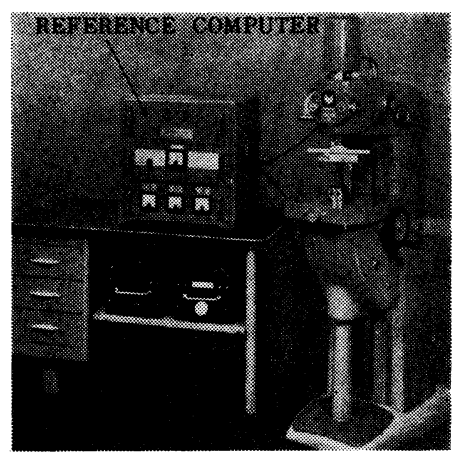

図 5 Talyrond と Reference Computer (Taylor Hobson 社製)

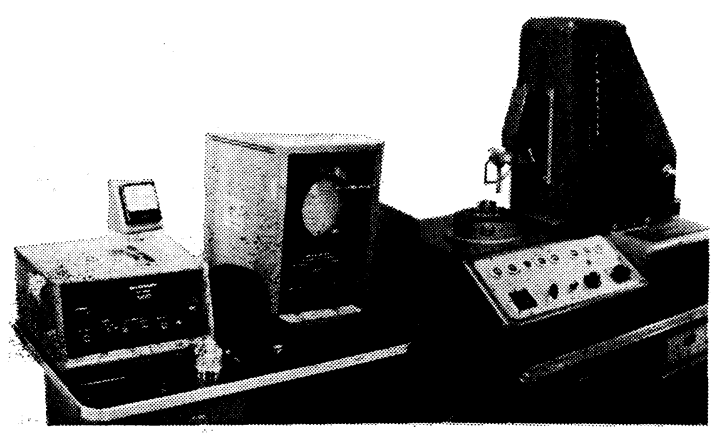

図 6 Formtester (Hommel Werke 社製)

とすると， $r<0.3 \mathrm{~mm}$ となる。図 7 は，B S で規定さ れているおの型と球型の 2 種類の測定子における先端形 状を示したもので，同図（a）に示すおの型測定子は同 図（c）の状態で，円形部分に接触させて用いる。そし て図中の各種の半径の大きさは, $r_{1}, r_{3}=0.025,0.25$,

$2.5 \mathrm{~mm}, r_{2}=12.7 \sim 25.4 \mathrm{~mm}$ と規定されている。また 図中 $b=1.58=2.38 \mathrm{~mm}$, 測定子の測定力は, 先端半径 最小のとき $1 \mathrm{gW}$ 以下, 先端半径最大のとき $20 \mathrm{gW}$ 以下 と定められている。 
<smiles></smiles>

(a)

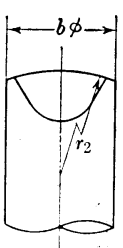

$\boxplus 7$

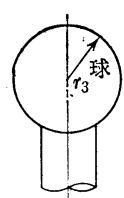

(b)

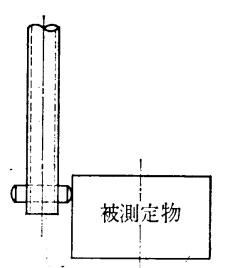

(c)

7 测定子の形状

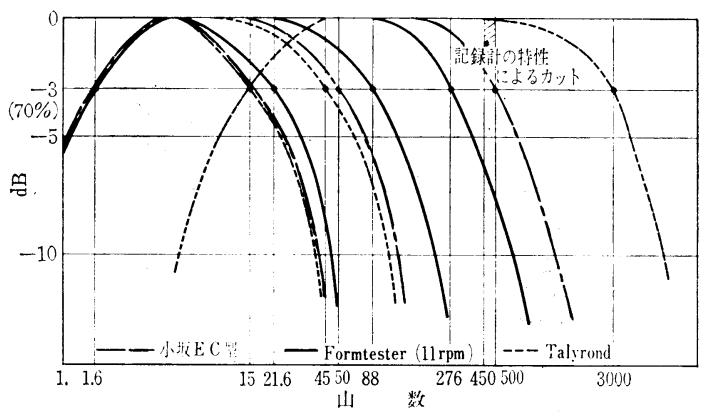

図 8 カットオフ特性
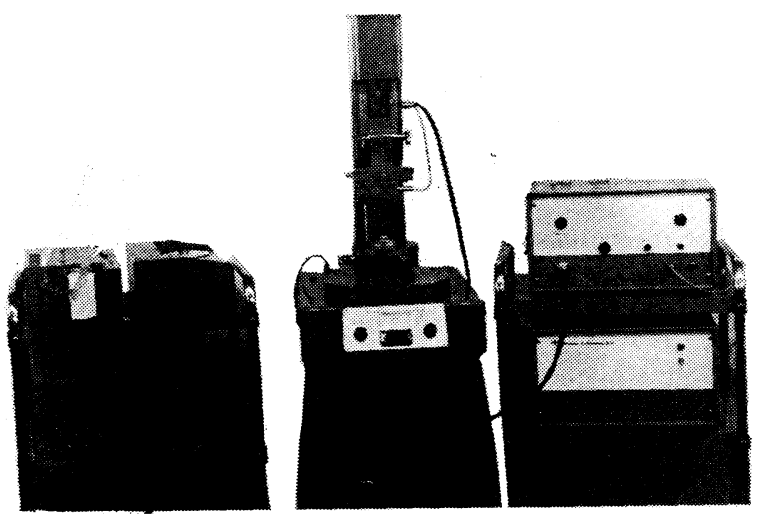

図 9 EC-1 型真円度測定器と Roundness Computer (小坂研製)

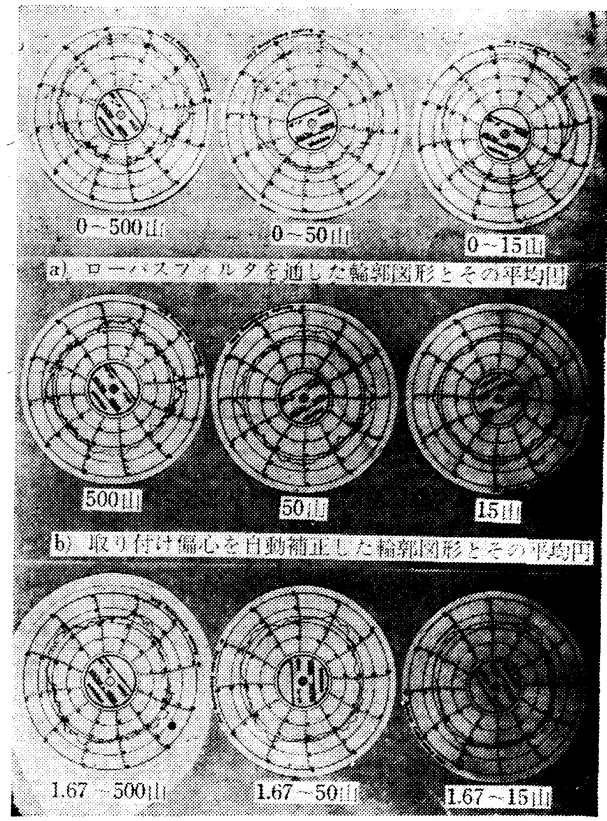

c) バンドパスフィル夕を通した輪郭图形と导の平均円

図 10 図 9 の装置による各種の記録四形

$$
f=\frac{N}{60} \times n_{\max }
$$

となる。ここで， $N$ は回転装 置の機構などで定まり，一般に 2〜10rpm である。したがって，

測定子の動特性は，表面あらさ測定に用いられる触針 の動特性と同じ理論6) 式で求められ，検出山数に追従で きる周波数特性を持っていなければならない。

\section{2 電気回路の特性}

測定子の動きを電気量に変換して測定する場合には, 主として電気回路の周波数特性を検討しておく必要があ る。

いま，最大検出山数を $n_{\max }$ とし，検出器または被測 定物の回転数を $N \mathrm{rpm}$ とすると測定子の動きの周波数す なわち電気信号の最大検出周波数 $f(\mathrm{c} / \mathrm{s})$ は, $N=10 \mathrm{rpm}, n_{\max }=500$ とする と, $f \fallingdotseq 83 \mathrm{c} / \mathrm{s}$ となる。このため 测定子の動きを電父量に变換する

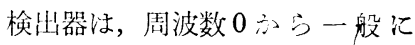
$100 \mathrm{c} / \mathrm{s}$ 程度までフラットな周波数 特性を持つことが必要で，差動変 压器がよく用いられる。

つぎに，検出器からの電気信号 には，最大検出周波数よりも高域

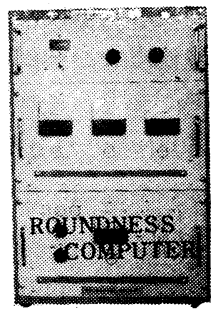

の周波数がふくまれているから，これをローパスフィル 夕回路によって，高域周波数をカットしなけれ将なな い。この回路のカットオフ值は, 利得が $3 \mathrm{~dB}$ 減じる点 で表わされ，減衰特性は普通 $12 \mathrm{~dB} /$ oct である。前に 述べた Talyrond, Formtester に用いられているカット オフ特性は図 8 に示すとおりである。また，図 9 亿示す EC-1 型真円度測定器 (小坂研究所製) のカットオフ值 は，500 山，50 山，15 山であって，その特性もまた図 8 に示してある。図10,a）は，被測定物の同一個所を 図 9 に示した装置で求めた記録図形であって, そのカッ 
表 1. 半径法真円度測定器とその主要な性態

\begin{tabular}{|c|c|c|c|c|c|c|c|c|c|}
\hline 製 品 名 & 公 社: 名 & 回転方式 & 検出方式 & 記録倍率 & 測定 & 範囲 & $\begin{array}{c}\text { 回転速度 } \\
(\mathrm{rpm})\end{array}$ & 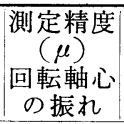 & その他 \\
\hline Taly rond & $\begin{array}{l}\text { Taylor, } \\
\text { Taylor of } \\
\text { Hobsm }\end{array}$ & 検出器の[日]転 & $\begin{array}{c}\text { 電気 式 } \\
\text { (差動変圧器) }\end{array}$ & $\begin{array}{l}\text { A. } 200^{-1} 10,000 \\
\text { B. } 100^{-} 5,000 \\
\text { C. } 50^{-} 2,500\end{array}$ & $\mid \begin{array}{c}3- \\
355\end{array}$ & $\begin{array}{l}1.5^{-} \\
355\end{array}$ & 3,35 , & 0.075 & $\begin{array}{c}\text { 被測定物 の } \\
\text { 最大高さ } 2 \text { 型 } \\
700 \mathrm{~mm}\end{array}$ \\
\hline Form teoter & $\begin{array}{r}\text { Hommal } \\
\text { Werke }\end{array}$ & テーブルの回転 & (電 気 式 & $50^{-1} 10,000$ & -150 & $\begin{array}{c}3- \\
150\end{array}$ & $5.5,11$, & 0.05 & $\begin{array}{l}\text { 高さ } 200 \mathrm{~mm} \\
\text { まで真 直 度 } \\
\text { 測 定 可 能 }\end{array}$ \\
\hline $\begin{array}{l}\text { Rotary- } \\
\text { Proficorder }\end{array}$ & $\begin{array}{l}\text { Maicrometical } \\
\text { Marufacturing }\end{array}$ & 検出器の回転 & $\begin{array}{l}\text { 電 気 式 } \\
\text { (差動変圧器) }\end{array}$ & $250^{-} 50,000$ & -200 & -200 & $\begin{array}{l}-0-12 \\
\text { (可変) }\end{array}$ & 0.08 & $\begin{array}{l}\text { 特 殊 型で は } \\
\text { 円 外径 } 380 \\
\text { まで測定可能 }\end{array}$ \\
\hline Indi-Ron & $\begin{array}{l}\text { Cleveland } \\
\text { Instrument }\end{array}$ & テーブルの回転 & $\begin{array}{l}\text { 電 気 式 } \\
\text { Indi-AC }\end{array}$ & $\begin{array}{l}400,2000 \\
10,000 \\
(50,000)\end{array}$ & $\begin{array}{l}1.5^{-} \\
150\end{array}$ & $\begin{array}{l}1.5^{-} \\
150\end{array}$ & 4, & 0.075 & $\begin{array}{l}\text { 平面度, 平行 } \\
\text { 度の测定可能 }\end{array}$ \\
\hline $\begin{array}{l}\text { Roundness } \\
\text { Measuring } \\
\text { Machine }\end{array}$ & $\begin{array}{l}\text { Optical } \\
\text { Measuring } \\
\text { Tools }\end{array}$ & 検出器の回器 & 空 気 式 & $\begin{array}{ll}1,000, & 1,250 \\
2,500, & 5,000\end{array}$ & $\begin{array}{l}1.6 \\
152\end{array}$ & $\begin{array}{c}3.2^{-} \\
152\end{array}$ & 1, & 0.12 & \begin{tabular}{|lll} 
回 & 転 & 軸 \\
空 気 & 軸 受
\end{tabular} \\
\hline Romdell & $\begin{array}{l}\text { Ellistt } \\
\text { Brathers }\end{array}$ & テーブルの回転 & 電 気 式 & $25-25,000$ & $\begin{array}{c}- \text { 約 } \\
105\end{array}$ & $\mid \begin{array}{c}2.5^{-} \\
\text {約 } \\
105\end{array}$ & $\begin{array}{l}3^{-21} \\
\text { (可変) }\end{array}$ & 0.06 & $\begin{array}{l}\text { 直角度, 平面 } \\
\text { 度, 平行度 } \\
\text { 制定可能 }\end{array}$ \\
\hline $\begin{array}{l}\mathrm{EC}_{1} \text { 型 } \\
\text { 真円度測定器 }\end{array}$ & (株)小坂研究所 & テーブルの回転 & $\begin{array}{c}\text { 電 気 式 } \\
\text { (差動変圧器) }\end{array}$ & $100^{-} 10,000$ & - & $\begin{array}{l}10^{-} \\
100\end{array}$ & 5 , & 0.2 & $\begin{array}{c}\text { 高さ } 100 \mathrm{~mm} \\
\text { まで真直度則 } \\
\text { 定可能, 精度 } \\
0.2 \mu\end{array}$ \\
\hline
\end{tabular}

トオフ值は刻帆示したとおりである。

\section{5. 取付け偏心補正}

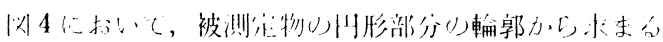

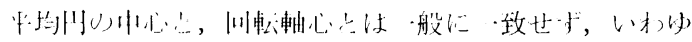

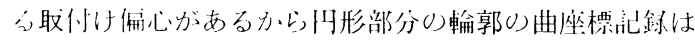

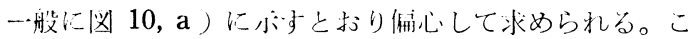
の编心量があまり大きいと，記録が得られないし，たと え記銢が得られても，㕸产が入り，湋った形状を想像さ せるこ上になる。

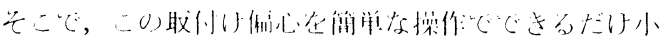

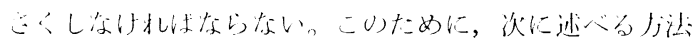
分溯ら机ている。

その一つは，取付り偏心があると測定子から得られる 電気信号には，1 回転につき 1 山に相当する信号が付加

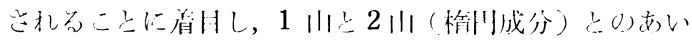

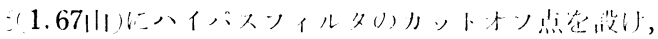

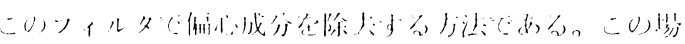

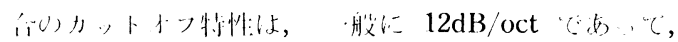

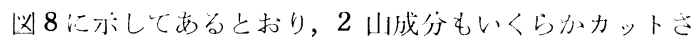
机ることになる。したがって，この方法では，形状波形 がずれる尔点があるが，便宜的に用いるには簡単なお

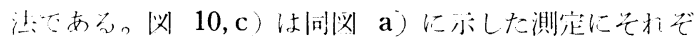

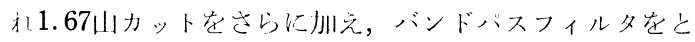
扎して求めた䛉錄であって，偏心成分がかなり除去され ていることがわかる。
他の一つの法は，偏心成分をらく電気信号によっ

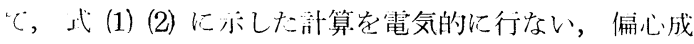

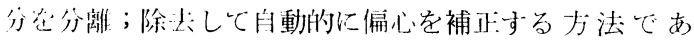
\%。

四2 に示すとおり，测定子が円形部分のまわりを，坐 標の原点 $O$ を中心として回転するとき, 測定子の動き 小ら得られる電気信号は図示の $O P i$ に相当する。そこ でこの信号から電気回路で $O P i \cos \theta, O P i \sin \theta$ 二つ の信号を求めれば，それぞれは，式(1)における $X, Y$ の 值になる。これより, 輪郭の平均円の中心の座標 $(\mathbf{a}, \mathbf{b})$ 老㲠父的に求めることができる。また，電気信号とのま まから式 (2) に上,で, 平均川の半径 $R$ が求まる。し たがって, 半径 $R$, 中心の位置 ( $\mathrm{a}, \mathrm{b})$ の平均円に相当 する電気信号により図 10, a) に示すとおり，偏心して いる記録図形中に平均円を画くことができる。一方，こ

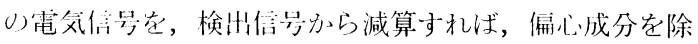

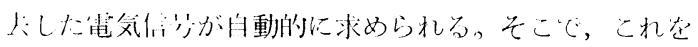

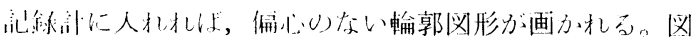

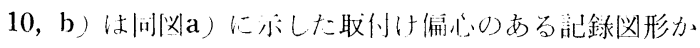
ら，上記の電気演算回路を用いて偏心信号を白動的に除 去して画いた記録である。図 5 , 図 9 に示す測定器には 忷示のとおり Reference Computer および Roundness Computer 走そ机ぞ扎接続させると，取付け偏心の白動 補正ができる。また，四７に示守測尘器には，自動補止 装置が内蔵されている。 


\section{6. 平均円中心方式真円度の測定}

平讼円中心方式真円度它記録四形から求めるには，前 述の力法で記録図形中にその平均円を画き，これと同心 の二つの円で闵形をはさみ，これら间心円の半経㾏を求 め机ばよい，この真円度を指示叶に指示させるには，众 出信号加ら偏心成分を除去した信号の最大の振れを求め 狆ばよい。すなわち, 偏心成分のない倍号は, 横軸を時 間軸にとると図 3 に亦与平均円を直線に展開した基準線 のまわりにある。そこで，基準線から，基準線つ1下に

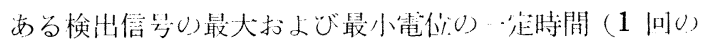

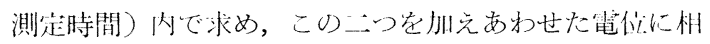
当する電流を指示計に流せば，指示計に平均真什度を指 示することができる。

つぎに, 図 3 で斜線部分の総面積, すなわち, 1 回の 測定時間内にある基準線と熋父信号とでかこまれた部分 の面積を，演算積分回路で求め，さらに，こ扎を1回の 測定時間 (これは円形部分の平均円の 1 円咸の長さに相

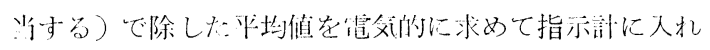

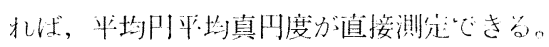

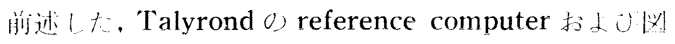
9 に亦しに EC-1 型真円度測公器に付属与るRoundness

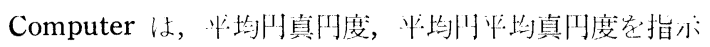
計に直接指示することができるようになっている。

\section{7. 最近の半径法真円度測定器の主要な性能}

最近, 電谷技術の芯用によって, 半往法真円度がは逨 のとおり容易に測分できるようになったのでここ婜の 測定器が湩々開発され，市骐さ机るようになった。これ らのうち主な測走器について，そい主要性能をまとめる
と表1のとおりである。この装からもわかるとおり，種 々の装置を付属させると平行度, 真值度および直角度を 測宝することができる。これは，最近の一つの傾向であ る。また，回転テーブルに览父マイクロメータを組み合 わせて测这する簡筩な測走器も製作されている。

\section{8. むす ひ}

以上のとおり, 半径法真川度の測宝について詳述し た。これは, 最近急激に㖄究開発されてきて, 能率的に

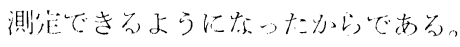

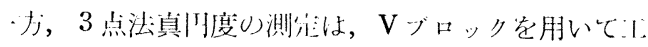
業的にすでに広く使用されているが，最近すぐれた研究 が行なわ机てきた。” これは，被測宛物の周囲に，口径 の異なる 3 個のノズルを配置する。このときノズルの口 径とその取付け位置とを計算值によって定めると, 被測 定物が，3 個のノズルの先端をとおる円のなかで偏心し ていても，この影響が打临されて空気マイクロメータに より，一種の3 吕法息归度が求められる。この方法は,

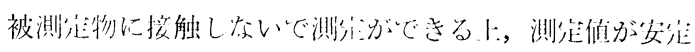

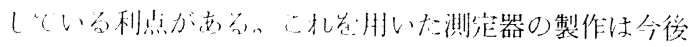

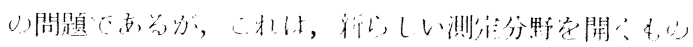

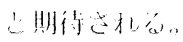

\section{参 考 文 献}

1) 鋤枘：総研所瓡 11 (将 39) 2 .

2) 沢辺：精機学:会春シンボジウム前删（昭40，249.

3) 味岡：精機学会春シンポジウム前刷(昭40)257.

4) 味岡：機械の研究 18-7 (刅41) 873 .

5) 青木, 大園：精機学侌秋季大会前刷（昭40） 301.

6) 味㡐: 精機学:会春季大会前刷(昭35).

7) 味阊, 川端：精機学:会秋季大会前刷 (昭41) 109.

8) 味阙, 川端：精機学丟秋季大会前刷 (㸃41) 111. 